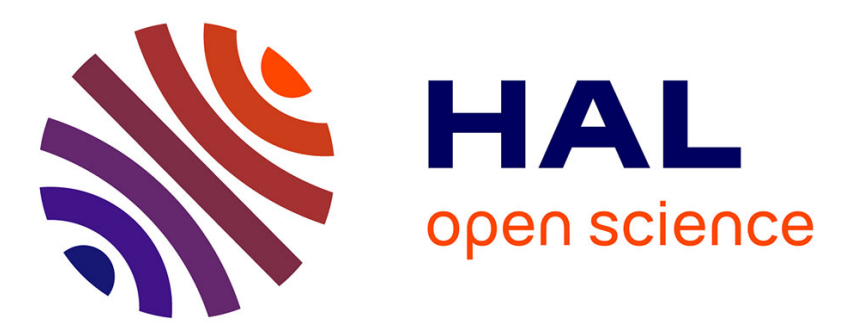

\title{
Wildfire frequency varies with the size and shape of fuel types in southeastern France: implications for environmental management
}

\author{
T. Curt, L. Borgniet, C. Bouillon
}

\section{- To cite this version:}

T. Curt, L. Borgniet, C. Bouillon. Wildfire frequency varies with the size and shape of fuel types in southeastern France: implications for environmental management. Journal of Environmental Management, 2013, 117, p. 150 - p. 161. 10.1016/j.jenvman.2012.12.006 . hal-00833426

\section{HAL Id: hal-00833426 \\ https://hal.science/hal-00833426}

Submitted on 12 Jun 2013

HAL is a multi-disciplinary open access archive for the deposit and dissemination of scientific research documents, whether they are published or not. The documents may come from teaching and research institutions in France or abroad, or from public or private research centers.
L'archive ouverte pluridisciplinaire HAL, est destinée au dépôt et à la diffusion de documents scientifiques de niveau recherche, publiés ou non, émanant des établissements d'enseignement et de recherche français ou étrangers, des laboratoires publics ou privés. 


\section{Wildfire frequency varies with the size and shape of fuel types in southeastern France: implications for environmental management}

\section{Thomas Curt, Laurent Borgniet, Christophe Bouillon}

Cemagref - UR EMAX Ecosystèmes méditerranéens et risques, 3275 route Cézanne - CS 40061, 13182 Aix-enProvence cedex 5, France

Corresponding Author: Thomas Curt (e-mail: thomas.curt@irstea.fr) 


\section{Abstract}

Characterizing time intervals between successive fires in the recent history is of main interest for fire hazard prevention and sustainable environmental management as it indicates what the typical fire return interval for each type of ecosystem is. We tested the extent to which fire return intervals (FRI) depend on fuel type and age, and we compared FRI values between two fire-prone areas of south-eastern France (Provence). These areas had similar weather and roughly similar fuel types but fuels occurred in patches with different sizes and shapes in the landscape. We built a fire database (1960-2010) and we fitted Weibull distributions of FRI in order to compute the probability density function and the hazard of burning. Our results indicate maximal probability of burning again for shrublands (garrigues and maquis), and minimal values for mixed broadleaf-conifer forests and broadleaved forests. Most fuel types of Provence showed no effect of fuel age on the probability of burning again. Only the unmanaged maquis showed a linear increase of fire hazard in time due to a rapid postfire fuel build up. Rather long fire-free intervals and low age-dependency for most forest fuels of Provence suggest that reducing their biomass may not be sufficient to reduce fire risk. In contrast, the flammable shrublands have rather short fire intervals and represent a high fire hazard for the whole study area. The two areas had statistically significant difference of fire return intervals for a same fuel type (e.g. 18 to 22 years for shrublands, 20 to 24 years for pine forests, and 24 to 27 years for oak forests). This suggested that size, shape and connectivity of fuels play a major role in the probability of burning again and should be taken into account for fire management. The present policy of fire prevention puts efforts into public information and prevention, and preferential management of fuels at risk in the vicinity of roads and wildland-urban interfaces where fires occur preferentially. However, fire suppression may also take advantage of favouring low-flammable fuels with low age-dependency on strategic places in the landscape.

Keywords: fire regime; fire interval; Weibull model; Mediterranean-type ecosystems; landscape management 
Author-produced version of the article published in Journal of Environmental Management, 2013, 117, 150-161 Original publication available at http://www.sciencedirect.com/

doi : 10.1016/j.jenvman.2012.12.006

\section{Introduction}

South-eastern part of France (so-called Provence) is a fire hotspot with ca. 35,000 fires burned during the 1973-2006 period and 8,500 ha burned annually on average (JRC-EFFIS, 2006). Provence also belongs to the biodiversity hotspot of the Mediterranean basin (Myers et al., 2000) and has a wide range of Mediterranean type ecosystems (MTEs) with shrublands, forests, and grasslands. Literature has long stated that fire is a key disturbance in such MTEs, which has a major impact on Humans, ecosystems, and landscapes (Moreno and Oechel, 1994; Pausas et al., 2008; Keeley et al., 2012). Previous studies in Provence have indicated that fire is an essential element in the vegetation dynamics, thus shaping the landscape mosaic (Curt et al., 2011; Schaffhauser et al., 2011). In Provence as in many MTEs of southern Europe, abandonment of former agricultural practices, afforestation policy and the increase of population were major drivers of fire risk during the past decades (In Moreira et al., 2011). Shrublands have expanded in the past decades because of the abandonment of former agropastoral management, and they sometimes constitute large tracts with high fire hazard (Curt et al., 2011; Schaffhauser et al., 2011). Extensive afforestation with conifer forests (mainly Pinus halepensis and P. pinaster) and their spontaneous expansion from planting (Barbéro et al., 2000) have strongly increased the fuel biomass and the connectivity of fuels on landscape scale. Thus, pine forests have been claimed to increase fire hazard in Provence, because they favoured intense crown fires (see Fernandes and Rigolot, 2007). Mixed pine-oak forests have a reputation for being highly flammable because of the vertical connectivity between the different species (see In Pausas et al., 2008). Only oak forests are considered to be low flammable and resilient due to a good resprouting ability (Pausas et al., 2008; Curt et al., 2009). Urban sprawl and the strong increase of population (Moreira et al., 2011) have favoured the development of road corridors and wildland-urban interfaces (i.e. the area where houses and the wildland vegetation coincide) where vegetation is generally extensively managed, with possible incidence on fire risk. The Provence area includes two neighbouring fire-prone areas with the same climate and roughly similar fuel types but with different size, shape and connectivity of fuels across the landscape: the Aix-Marseille area and the Maures massif. This configuration provided a unique opportunity to investigate if fire frequency was similar for a given fuel type but different patch size and connectivity. This has implications for management, because if fire frequency is similar for a certain fuel type in both areas then similar management should be applied.

In this context, it is crucial for sustainable management to characterize the fire frequency specific to each type of ecosystem (hereafter referred to as 'fuel types', i.e. identifiable associations of fuel elements of distinctive species that will cause a predictable fire behavior; Pyne et al., 1996). It is noteworthy that although the Provence area is a fire hotspot, no georeferenced fire database existed yet. This prevented any accurate fire frequency analysis whereas it existed in neighbouring countries such as Spain (e.g. Diaz-Delgado et al., 2001) or Portugal (e.g. Oliveira et al., 2011). This may explain why controversy still persists among land managers in Provence about the role of fuel age and the typical fire return interval for the most common fuel types. Literature stated that characterizing the past fire regime, i.e. spatial pattern, frequency, intensity and seasonality of fires prevailing in an area (Gill, 1975; Pyne et al., 1996) is necessary to assess fire risk and the ecosystem vulnerability. Fire frequency is a main feature of fire regime which is notably characterized by fire intervals, i.e. time in years between two successive fires in a designated area. First, this key component has major implications for fire risk assessment since it is important to predict the mean fire return interval or the probability of a new fire after having burned (Moritz et al., 2009). Secondly, fire intervals control in part the survival and regeneration of many species (Pausas et al., 2008) and thus the dynamics and sustainability of wildland and forests. As a consequence, the characterization of fire return intervals (FRI) has been increasingly used to guide forest management to prevent fires by fuel treatment (Keeley et al., 1999; Fernandes and Bothelho 2003), to mimic the natural disturbance regime in order to maintain biodiversity (Martin and Sapsis, 1992; Burrows 2008), or to 
Author-produced version of the article published in Journal of Environmental Management, 2013, 117, 150-161 Original publication available at http://www.sciencedirect.com/

doi : 10.1016/j.jenvman.2012.12.006

limit the risk of species extinction in fire-prone ecosystems (Allen et al., 2002). It has been proved that fires at inappropriate time intervals may change the quality of habitats (Burrows, 2008) or lead to the extinction of interval-sensitive species (Eugenio et al., 2006; Pausas, 2006; Russell-Smith et al., 2010).

The distribution of FRI in a landscape results from the recurrence and the patterning of fires which in turn results from a complex stochastic process of ignition, spread, and regrowth dynamics (Moritz et al., 2009). Interactions between ignitions sources, weather, topography and land cover explain why some locations burn more often than others in a landscape (Mermoz et al., 2005; Moreira et al., 2011). In many MTEs, ignition is man-induced (Moreira et al., 2011) then favoured by weather. As a result, most points of ignition aggregate in road corridors (Curt and Delcros, 2010) or wildland-urban interfaces (Lampin-Maillet et al., 2010) and fuel types located in the vicinity of these areas are likely to burn more frequently than others. FRI should also strongly depend on factors controlling fire spread within the landscape, including physiography and fuels. In French or Spanish MTEs it has been proved that fire recurrence is higher on certain topographic positions (e.g. south facing slopes and crests; Mouillot et al., 2003; Vazquez and Moreno, 2001) due to a combination of factors linked to ignition, topoclimate, and fuels (Moreira et al., 2011). Fuels can play a major role in variations of FRI as certain fuel types or land covers are especially flammable because of their composition, biomass, structure, and moisture. Higher fire selectivity for shrublands rather than for forests and almost agricultural lands has been stated in many MTEs (see In Moreira et al., 2011). Some fuel management practices such as forest thinning, planting or shrub-clearing would also affect the probability to burn (or to reburn) and to propagate fire because they modify the biomass and spatial arrangement of fuel. As FRI express the probability of reburning within a certain time period, it also depends upon the ability of a fuel to recover after fire or to shift to another fuel type (Moritz et al., 2009). Some fuel types exhibit rapid postfire fuel build-up whereas others can stay for a long time with fuel load insufficient to carry a new fire ('fuel limitation' stage). A feedback exists between fuels and fire (i.e. fuels produce fires and, in turn, are affected by fires), and a typical FRI is expected to settle down for a certain duration in a certain landscape (Turner, 1989).

In the study we assessed the fire return intervals for two fire-prone areas in Provence, based on an original georeferenced fire database from 1960 to 2010 including all fires larger than ca. 3 ha. First, we tried to find out what the typical FRI for each fuel type was. This knowledge is crucial to guide the type of management to apply to ensure the ecosystem sustainability. For that purpose we computed the FRI for each fuel type and area using both censored and uncensored data. Censored data take only into account fire intervals between two fire dates known precisely while uncensored include all data. Then, we tested the hypothesis that FRI could differ from one area to the other for a same fuel type (and a similar climate) due to a difference of size, shape and connectivity of fuels. For that purpose we compared FRI for a same fuel type in the two areas. Our final objective was to advise what type of fuel management could be applied to the main fuel types existing in Provence.

\section{Materials and methods}

\subsection{Study areas}

We selected two study areas within the Provence fire hotspot since it enabled us to compare FRI with similar climate and fuel types but with different size, shape and connectivity of fuels across the landscape. The Aix-Marseille area (called below AIXM; central point: $43^{\circ} 20 \mathrm{~N}, 5^{\circ} 23 \mathrm{E}$; area 510,593 ha) has ecosystems on limestone-derived soils dominated by Pinus halepensis, Quercus ilex and Quercus pubescens, and Quercus coccifera shrublands (Appendix 1A). The Maures massif (called below MAUR; central point $43.3^{\circ} \mathrm{N}, 6.3^{\circ} \mathrm{E}$; area $145,686 \mathrm{ha}$ ) is made of a gneissic substratum and has 
Author-produced version of the article published in Journal of Environmental Management, 2013, 117, 150-161 Original publication available at http://www.sciencedirect.com/

doi : 10.1016/j.jenvman.2012.12.006

siliceous soils. Its ecosystems are dominated by Pinus pinaster, Quercus suber (with Q. pubescens and $Q$. ilex), Erica-Cistus shrublands (Appendix 1B). Fuels are roughly similar in these two areas with the exception of mixed forests (Appendices 1A-1B; Fig. 3).

Conversely, the two areas exhibit a high contrast of size, shape and connectivity of fuels in the landscape. The Maures massif is dominated by wildland with sparse cork oak woodlands intermingled with large extents of flammable Erica-Cistus maquis (Fig. 1B). In contrast, the AixMarseille area is a matrix of fragmented and interspersed pine and oaks forests, with small patches of Quercus coccifera garrigue. In addition, wildland and forests are almost absent in the western part (Fig. 1A) which is dominated by agriculture, industries, and salt pans. The two areas are close to each other and have the same climate making them conducive to frequent and intense summer fires (JRCEFFIS, 2006). Both areas had roughly similar fuel types including shrublands, pine forests, oak forests, and mixed pine-oak forests. Shrublands are fire-prone ecosystems dominated by seeders (e.g. Cistus spp., Ulex parviflorus) or resprouting species (e.g. Quercus coccifera, Erica arborea) that have evolved to adapt to fire (Pausas 2006) and are generally flammable (Curt et al., 2011). They have low fuel moisture content during the summer season (Schaffhauser et al., 2011). Pine forests can generate surface fires of moderate intensity (fireline intensity $<2000 \mathrm{~kW} \cdot \mathrm{m}^{-1}$ ) or high-severity crowning fires depending upon the pine species and the stand structure (Rigolot, 2004; Fernandes et al., 2008). In both areas, the climate is typically Mediterranean, classed as subhumid xerothermic (Quézel and Médail, 2003) with a mean annual rainfall of ca. $550 \mathrm{~mm}$ and a mean annual temperature of $15.9^{\circ} \mathrm{C}$, and high interannual and seasonal variability. The summer period is characterized by severe droughts associated with strong wind, which favour fire ignition and propagation.

\subsection{Assessment of fuel and landscape characteristics}

Fuel composition, fuel biomass and fuel patterns in the landscape have been studied extensively in previous studies in both areas. First, we established $20 * 20 \mathrm{~m}$ plots in the different fuel types, and we described live and dead fuels according to a standard protocol. Fuel particles of different size were then collected and oven-dried to get the dry biomass. Detailed information on field and laboratory protocols are available in previous studies (Ganteaume et al., 2009; Curt et al., 2011; Schaffhauser et al., 2011). The main characteristics of fuels are described in Appendices $1 \mathrm{~A}$ and 1B. In order to make simpler comparisons we regrouped the fuels into four main fuel groups having different FRI values: shrublands, pine forests (including those of WUI and road corridors), mixed forests (pine-oak mixings), and oak forests (Fig. 3).

Secondly, we characterized spatial patterns of fuel and fires on landscape scale using the Geographical Information System ArcGis 9.3 (ESRI, Redlands, CA, USA) and the Patch Analyst and Patch Analyst for grid programs v. 4.2.13. Thanks to it, we could compute landscape metrics for the different fuel types: (i) the mean patch size, which indicates how large the patches of each fuel type are; (ii) the mean perimeter/area ratio, which indicates if the fuels patches are irregular or not; and (iii) the area weighted mean shape index which increases as the patch shape becomes more irregular (Table 1). These indices were used to investigate if the size and connectivity of the fuels patches and the burned scars were different in the two study areas. Indeed, we hypothesized that the AixMarseille had a very patchy mosaic of fuels with a smaller grain than the Maures area, which would limit the probability of having very large fires burning frequently the same fuel patches. We also used the FragStat software (McGarigal et al., 2002) to compute a fuel contagion index which reflects dispersion (i.e. the spatial distribution) and intermixing of patch types on raster maps (pixel size 100 $\mathrm{m}$ ) over each landscape. The index is computed from the frequencies on which pairs of fuels occur as adjacent pixels and it varies from 0 (maximal dispersal of pixels of fuels over the landscape) to 100 
(all pixels of fuel are adjacent). For this purpose we coded all fuel types (shrublands and forests) as 1 and non-fuels (including agricultural lands, cities, roads) as 0 . The contagion index was intended to indicate to which degree fires may theoretically propagate throughout the flammable fuels within each study area (Table 1). We also computed a contagion index specific to the shrublands and one specific to the forest, for each study area. These indices were computed in order to test to which degree shrublands and forests may favour the propagation of fire in each area. We also computed the MESH and SPLIT indices. MESH equals the sum of fuel patch area squared, summed across all patches of the corresponding patch type, divided by the total landscape area $\left(\mathrm{m}^{2}\right)$. It is maximum when the landscape consists of a single patch. The SPLIT index equals the total landscape area $\left(\mathrm{m}^{2}\right)$ squared divided by the sum of patch area $\left(\mathrm{m}^{2}\right)$ squared, summed across all patches of the corresponding fuel patch type. SPLIT is equal to 1 when the landscape consists of single patch, and increases as the focal fuel patch type is increasingly reduced in area and subdivided into smaller patches. We compared the values of the different landscape metrics between the two areas using the Mann-Whitney-Wilcoxon $W$ test or the Tukey HSD test with $\alpha<0.05$, using the R statistical software (R Development Core Team, 2011).

\subsection{Georeferenced fire database}

We built fire recurrence maps for both study areas (AIXM and MAUR) on the basis of a comprehensive study of burn scars visible on a set of satellite images (1960-2010; Fig. 1). A first set of georeferenced burn scars had been drawn in the field by foresters and fire-fighters for the older fires (1960-1985). They have been gathered, checked and redrawn individually, completed using Landsat images with MultiSpectral Scanner (MSS, spatial resolution $80 \mathrm{~m}, 1973-1983$ ), then using TM and ETM (Enhanced Thematic Mapper, resolution $30 \mathrm{~m}$ ) since 1983. Since 1999 we have also used satellite images (MODIS, resolution $250 \mathrm{~m}$ ) using semi-automatic recognition by the multi-dates comparison of the normalized vegetation index (NDVI) (see Curt et al., 2011 and Schaffhauser et al., 2011 for details). In practice, we checked for every fire listed in the French fire database 'Prométhée' (http://www.promethee.com) since this database gives the date, the point of ignition and the estimated size of all fires since 1973. From this information, we assessed the NDVI value all around the likely location of the fire. NDVI data were extracted from the so-called 16 days Vegetation Index Products (MOD13Q1) with 250m resolution images one month before and after the fire. This VI compositing algorithm includes the maximum value composite (MVC) and a constraint on view angle - maximum value composite (CV-MVC). This technique of compositing data reduces noise in the surface reflection signal including QA data sets with statistical data indicating the quality of the VI product (Gu et al., 2009). The comparison of the value before and after the fire confirmed if a fire occurred; a threshold of 0.5 for the $\Delta_{\mathrm{NDV}}$ was considered as indicative of a fire. The final contour of the burn scar was drawn using Landsat images. Finally, we used only the fires larger than 3 ha because smaller fires may have not been detected (and thus, underestimated). Fire maps were created for each year under analysis (1960-2010, then pooled together using the Geographical Information System ArcGis 9.3 (ESRI, Redlands, CA, USA). The time intervals between successive fires have been extracted for all fires using a $25 \times 25$ meters regular grid. In example, if a certain pixel burned in 1990, then in 2003 and 2010, the two times intervals were 13 and 7 years respectively. For each pixel of the $25 * 25$ meters grid we collected the information on the fuel type at different dates to account for changes that could have occurred over time in a pixel. For this purpose we used maps of vegetation (National Forest Inventory, spatial resolution 60 to $30 \mathrm{~m}$; http://www.ifn.fr/spip/) and land cover (Corine Land Cover, spatial resolution 100 m; http://www.eea.europa.eu/fr) for 1975, 1984, and 2004. To each pixel was assigned the vegetation type existing at the time just before the date of fire.

\subsection{Modelling the fire return intervals}


Fire frequency analysis is considered as a branch of pyrostatistics (Moritz et al., 2009). When characterizing FRI using a survival analysis (Smith, 2002; Lawless, 2003), fires are considered 'deaths' and fire intervals represent survival time (Johnson and Gutsell, 1994). Thanks to that we can assess FRI on time series for a given landscape by computing hazard functions which reflect how the probability of fire changes with the age of fuels. Such analysis requires accurate fire data during a time period sufficient to let successive fires to burn some locations and to account for temporal heterogeneity, i.e. a minimum of several decades for many MTEs experiencing frequent fires (Oliveira et al., 2011). Few FRI studies of are available in MTEs due to the lack of such fire databases. Fire-frequency analysis has been proposed to test the extent to which fuel age could influence the fire incidence (e.g. Moritz et al., 2004b). Actually, controversy about the environmental drivers of fire intervals in many MTEs has risen in the past years. For some authors, fire occurrence in shrublands and conifer forests is time-dependent and fire hazard would increase with the age of fuels (Minnich, 1983; Minnich and Chou, 1997), while others suggest little role for fuel age (Moritz et al., 2004b; Keeley and Zedler, 2009). This debate expanded to different MTEs such as the South-African fynbos (van Wilgen et al., 2010) or the Australian woodlands and shrublands (O'Donnell et al., 2011). It has ecological and management implications: if fire hazard increases with fuel age, then fuel management would be effective to limit future fires thus justifying extensive fuel treatment.

Fire data are typically a combination of uncensored and censored fire intervals (Moritz et al. 2009), censored values being those prior to the first fire on record, and those following the last fire on record. Thus, censored values (Polakow and Dunne, 1999) take only into account fire intervals between two fire dates known precisely. This censoring limits the size of the fire database but this is essential for estimating correctly the fire return interval and to avoid biases in the $b$ and $c$ parameters of the Weibull function (see below; Moritz et al., 2009). The fire interval can be complete (i.e. bounded on both ends with known dates) or not (Polakow and Dunne, 1999). Moritz et al. (2009) have explored the consequences of using censored or uncensored fire data and concluded that disregarding censored data may cause distortion of the real fire hazard. Recently, Oliveira et al. (2011) have also tested this effect for FRI during the 1975-2005 period for the whole Portugal and confirmed that censoring fire data has a predominant effect on FRI. It is likely to be especially important when the database comprises few fire intervals (e.g. a short record coming from a frequent fire system or a long record in a system with very infrequent fires). In this paper we used both complete censored data (called below 'censored') and uncensored data in order to investigate the extent to which this could change the results.

We fitted a Weibull model to the distribution of fire intervals at our sites, using our fire atlas. The Weibull model (see Johnson and Gutsell, 1994) has been proved flexible and able to provide superior fit to fire history data than most other distributions (see Grissino-Mayer et al., 2004). Using this model, the distribution of fire intervals can be described in two complementary forms: $F(t)$ gives the probability of fire occurrence before or at a time $t$, and $f(t)$ is the probability density function reflecting the frequency of burning in a given time interval (Moritz, 2003; Moritz et al., 2009) as follows:

$$
\begin{aligned}
& F(t)=1-\exp \left[-(t / b)^{c}\right] \\
& f(t)=\left(c t^{c-1} / b^{c}\right) \exp \left[-(t / b)^{c}\right]
\end{aligned}
$$

where $t>0, b>0$ and $c \geq 0$. The parameter $b$ is the scale parameter related to the expected interval between fires, while $c$ is the shape parameter, which shows how the hazard of burning changes with time since the last fire. The parameters $b$ and $c$ have ecological meaning: the scale parameter $b$ is the typical 63.2 percentile of fire intervals (i.e. the typical fire return interval surpassed $36.8 \%$ of the 
time, in years; Polakow and Dunne, 1999) while the $c$ shape parameter indicates the change in fire probability through time (see below). The hazard of burning function $\lambda(t)$ gives the probability of a fire to occur within a specific time interval (Moritz et al., 2004a):

$\lambda(t)=c t^{c-1} / b^{c}$

where $t$ is the time since the last fire, and $b$ and $c$ are estimates of the Weibull model. This hazard of burning function is useful because it typically reflects how the probability of fire changes with the age of fuels. Actually there is still a debate on whether fuel age (or the time-since-the-last-fire) may have an impact on fire recurrence or not. In short, some authors (Minnich, 1997) argue that large fires are fuel-driven while others argue that they would be mostly climate-driven (Keeley et al., 1999; Moritz et al., 2004a). This issue can be solved using the Weibull's $c$ shape parameter. Indeed, values of $c=1$ reflect no change in hazard of burning with time, while $1<c<2$ indicates a hazard growing with a diminishing rate, $c=2$ indicating a linear increase, and $c>2$ indicating an increasing hazard with time (see Moritz et al., 2004a). A c value of 1.42 is considered the maximum estimate for a combined fuelweather effect for Californian chaparral (Polakow and Dunne, 1999; Moritz et al., 2004a).

We computed these Weibull equations on fire intervals between 1960 and 2010. The $b$ and $c$ parameters were estimated by maximizing the likelihood function, and the Kaplan-Meier reliabilities to the positions of the points plotted by the survival analysis (Dodson, 2006). We tested the goodness-of-fit using a Kolmogorov-Smirnov test. In addition, we also computed the median fire return interval (also called the median fire-free interval, MEl; Grissino-Mayer, 1999) for each fuel type, using the estimate on which the proportion of the area surviving without a successive fire is 0.5 in the generalized Weibull model (van Wilgen et al., 2010), accounting for censored values. MEI is computed as:

$\mathrm{MEI}=\mathrm{b}(\ln 2)^{(1 / \mathrm{c})}$

For each area we also computed the fire cycle (Johnson et al., 1999; Crow et al., 1994) or the natural fire rotation period (NFR) as the length of time required to burn the equivalent of a specified area (Heinselman, 1973; Agee, 1993):

$N F R=\frac{N}{A / S}$

Where $N$ is the number of years during the period studied, $A$ is the total area burned, and $S$ is the total study area.

\section{Results}

During the 1960-2010 period, a total of 1,451 fires larger than 3 ha have been considered for the AIXM area (sum of 78,860 ha burned), and 217 fires (sum of 59,606 ha burned) for the MAUR area (Fig. 2). The two areas had contrasted fire and fuel patterns: MAUR had much less fires but they were much larger than AIXM, and MAUR burned more extensively and frequently. As a result, the fire cycle was much lower for MAUR (Table 1). This area had also larger fuel patches, especially for shrublands although the proportion of shrublands in the landscape was similar in the two areas (ca. $55 \%$, Table 1). The resulting fuel contagion index was clearly higher for MAUR than for AIXM for shrublands, forests, and the whole landscape (Fig. 4). The contrast of fire patterns in the landscape was clearly visible on Fig. 1. In the MAUR area, large and superimposed fires correspond to large patches of maquis located in the western and eastern parts of the massif, while a part of the central massif covered with mature oak forests and chestnut coppices has remained unburned (Fig. 1B). In the AIXM area, fires are much smaller and fragmented, and they are mostly located on the eastern 
part of the region dominated by wildland and forest. The characteristics of the main fuel groups were roughly similar in the two study areas (Fig. 3). Only the mixed fuels (mainly pine-oaks mixings) had significantly higher tree cover, fuel bed depth and 1-h fuel load in AIXM.

The mean time interval between fires (FRI) varied not much across the study areas (ca. 18 to 31 years; Appendices $2 \mathrm{~A}$ and $2 \mathrm{~B}$ ), although differences between fuel types were higher for MAUR. For most fuel types of both areas, censoring the fire data clearly increased the value and the range of the $b$ parameter while it decreased the value of $c$ (Appendices 2A and 2B). The mean FRI and median fire-free intervals (MEI, censored values) were minimal for shrublands in both study areas (Appendices $2 \mathrm{~A}$ and $2 \mathrm{~B}$ ). The AIXM area showed clear differences of fire intervals and of the Weibull's $b$ parameter between fuel types (Appendix 2A). The lowest MEl values were recorded in garrigues. Intermediate values (ca. 30-35 years) were for pine forests, sparse woodlands and spontaneous afforestation (dominated by pines), and fuels of road corridors dominated by shrubs and grasses. Oak forests, pine-oak mixings and fuels of WUI (often shrub-cleared) had clearly longer fire-free intervals and $b$ parameter. The $c$ parameter was strikingly low for all fuel types of AIXM, which resulted in slow increase of hazard of burning with time in comparison to MAUR (Fig. 5). In the MAUR area, MEI and the $b$ parameter varied much less (Appendix 2B). However, the different subtypes of maquis had lower values than the forests types including cork oak, mixed oaks or pineoak mixes. The $c$ parameter was clearly low for all forest fuels (1.19 to 1.37) while it was close to 2 for all maquis (Appendix 2B). The figure 5 displayed the hazard of burning $\lambda(t)$ for the four main groups of fuels in both areas. It showed that the MAUR maquis had clearly higher hazard of burning over time than all the other fuels, and especially than the AIXM garrigues. Indeed, the hazard of burning strongly increases in the Maures maquis beyond 10 years after a fire.

\section{Discussion}

\subsection{The interplay between landscape, fuels and fire}

Our study areas showed contrasted patterns of fires (burned scars) and fuels on the landscape scale. The Maures massif was 3.5 times smaller than the Aix-Marseille area. It had large homogeneous fuel patches of shrublands and forests favouring the contagion of fire across the landscape. Indeed, it had large fires distributed evenly across the landscape and often superimposed although having a low fire occurrence. This resulted in a short fire cycle. This also corresponds to a specific patterning of ignitions: most of them occur around the Maures massif in the vicinity of roads, WUI and resorts, then large fires spread throughout connected maquis and cork oak forests within the massif (Curt et al. 2011). This feature has favoured a positive fire-fuel feedback and the expansion of maquis during the past decades (Schaffhauser et al. 2011). In contrast, the Aix-Marseille area had fuels fragmented with a fine grain across the landscape, numerous but small fires, and these fires were less superimposed. This logically resulted in a much longer fire cycle. In this area, ignitions occur throughout the whole area along the dense network of roads and WUI, but fire spread is limited by the fine-grained fragmentation of shrubland and forest patches.

This interplay between fires and landscape generated a striking contrast between the two neighbouring areas: ca. $41 \%$ of the MAUR area was burned at least once during the last five decades against only ca. $15 \%$ for AIXM. These two areas had similar weather and causes of fires (and ignition rates), and the limited differences between the characteristics of fuel types suggest that this may not be sufficient to generate such contrast with fire recurrence. We suggest that the size, shape and connectivity of fuels across the landscape may have affected fire recurrence. This result is in line with the findings of O'Donnell et al. (2011) in semi-arid shrublands and woodlands of Australia, where the spatial variation of fuels and their connectivity across the landscape control the fire intervals. 
The use of a same distribution type (i.e. the Weibull model) applied to fire interval data on a same time span provided a standard system for comparing the fire regimes of AIXM and MAUR. For AIXM, censored data showed increasing fire intervals from garrigues to pine forests, oak forests, then and mixed forests. But fuel age has a low effect on fire hazard whatever the fuel type is, even for the garrigues which recover their fuel biomass rapidly after a fire. The low values for the Weibull's $c$ parameters $(1<c<2)$ indicate a hazard growing with a diminishing rate, and thus suggest a limited role of fuel characteristics and the predominance of weather (Keeley et al., 1999; Moritz et al., 2004a). Only the maquis in MAUR exhibits a $c$ parameter close to 2 , which indicates a linear increase of fire hazard over time.

Shrublands of both study areas are undoubtedly the most likely fuels to reburn since they have low fire intervals in comparison to forests. Actually, shrubby fuels are long acknowledged fireprone in many MTEs throughout the world (Moreira et al., 2001; Mouillot et al., 2002; Baeza et al., 2006; Syphard et al., 2007; Saura-Mas et al., 2010). Many shrubs common to MTEs (Quercus coccifera, Erica arborea, Cistus spp., Ulex) have been proved highly flammable due to a high amount of fine and dead fuel particles, low fuel moisture content during summer, and chemical compounds (Baeza et al., 2006; Saura-Mas et al., 2010). In addition, shrublands of Provence contain high proportion of flammable grasses such as Brachypodium retusum which favour ignition (Curt and Delcros, 2010; Curt et al., 2011). Once ignited, these fuel types generally generate rapid crown fires of medium- to high intensity which can propagate over large areas (Pausas et al., 2008; Curt et al., 2011). The MAUR maquis had an almost linear effect of fuel age, which fits with the fact that most shrublands are renowned for having rapid post-disturbance recovery of fine biomass (generally within 9 to 26 years, Trabaud, 1998; Fernandes et al., 2010) that would favour rapid reburning. In Portugal, shrub-dominated areas exhibit rapidly increasing hazard of burning with fuel age; $c$ values ranging from 2.6 to 4.8 (Fernandes et al., 2010). In the MAUR maquis, postfire fuel accumulation is very rapid due to the predominance of efficient seeder shrubs (notably Cistus) which colonize the gaps after fire, and of efficient resprouters such as Erica arborea. Both have flammable live fuels (Schaffhauser et al., 2011) and dead fuels (Curt et al., 2011). A positive feedback likely exists between fire and shrubs abundance since most areas burned recurrently turn into flammable shrublands (Curt et al. 2011; Moreira et al., 2011; Mouillot et al., 2003; Diaz-Delgado et al., 2004) due to the predominance of auto-succession (Trabaud 1998; Lloret, 2002; Acácio et al., 2009). In contrast, the hazard of burning tends to decrease over time in the AIXM area. First, this counter-intuitive finding may be explained by the fact that many already burned areas turn into bare soil. Secondly, limestone-derived soils are low fertile and postfire recovery of Quercus coccifera garrigue is rather long (Trabaud 1998), thus making shrublands on limestone substrate less flammable than those on siliceous soils (Fernandes and Botelho 2003). Thirdly, the recent policy of fire prevention has promoted shrub clearing in strategic places to establish firebreaks, notably in areas already burned. This study defends the strategy of reducing the biomass of shrublands in strategic places (WUI, road corridors, and fuelbreaks) to limit future fires, using notably prescribed fire and sylvopastoralism. However, fuel reduction has been proved effective to limit reburning only during few years in most shrublands (generally 2-4 years; Fernandes and Botelho, 2003; Moritz et al., 2004b; van Wilgen et al., 2010), and only if fire weather is not severe or extreme (Moreira et al., 2011). In the MAUR massif particularly, the expansion of maquis challenges the efforts for fire prevention and fire-fighting.

Conifer forests were renowned among forest managers for conferring high fire hazard over the Provence landscape. This study confirms they have rather short fire intervals due to their high flammability and combustibility but low hazard of reburning, indicating that the fuel rebuilding after a fire is rather slow. On the one hand, $P$. halepensis in AIXM and $P$. pinaster forests in MAUR are highly flammable due to a heavy fuel load and high amount of fine particles which burn readily (Ganteaume et al., 2011; see also Dimitrakopoulos et al., 2007; Alessio et al., 2008; De Lillis et al., 
2009). Many Mediterranean pines thus cause high-intensity fires, including crown fires (Fernandes and Rigolot 2007). On the other hand, pine forests of Provence fortunately exhibit low effect of fuel age after a fire. This is coherent with the low fuel accumulation over time in the overstory: understory grasses and shrubby fuels decrease rapidly with stand closure and maturation, thus reducing the fire hazard (Fernandes, 2009). The reputation of Pinus halepensis forests to generate fire risk is likely due to its large expansion throughout Provence during the past decades (Barbéro et al., 2000), especially after grazing cessation. In that case, pines expanded in shrubby and grassy fuels, thus creating very flammable fuels. A firewise way to manage these fuels is to thin and prune trees, clear the shrubs understory, and favour the establishment of oaks. This may direct them towards less flammable fuels in the medium-term (see Pausas et al., 2008). In the Maures massif, although being especially fire-resistant (see Fernandes and Rigolot 2007), Pinus pinaster has strongly retracted after recurrent fires and postfire pests and diseases. $P$. pinaster is only a strong danger when mixed with maquis, because it can generate high-intensity crowning fires.

Fuel types typical of WUI and road corridors have lower fire intervals than forests, confirming their fire-proneness. WUI and road corridors are preferential areas for ignitions due to the proximity of human activities causing most fires. However, the effect of fuel age for these fuels remains low owing to the fact that these areas are often intensively managed to prevent fire spread. We also suspect our database to be biased for these fuels since most fires are very small due to the rapid intervention of fire fighters and the small size of fuel patches. Actually, very small fires (e.g. $<1$ ha) were not mapped in our database.

Mixed pine-oak forests and almost broadleaved forests (Quercus ilex, Q. pubescens, Castanea sativa) have long fire intervals and no effect of fuel age on fire hazard. This suggests a low and slowly increasing hazard after a fire, coherent with the low flammability of these fuels due to the low ignitability of their litter (Curt et al. 2011) and to the slow increase of fuel biomass with stand age (Schaffhauser et al. 2011). Where no fire occurred over the past 50 years, most mixed conifer-oak forests have progressively turned into oak-dominated forests (Curt et al., 2009; Schaffhauser et al., 2011). Some have suffered few fires of low to medium intensity, which have opened windows of regeneration for oaks (e.g. Pausas et al., 2008 for Spain). Cork oak (Q. suber) forests of the MAUR area burned more frequently due to the expansion of surrounding maquis. As stated by Acácio et al. (2009) in Portugal, this protected habitat tends to shift towards shrublands due to a combination of droughts, fires and plant competition (Curt et al., 2009).

\subsection{Comparison with other MTEs}

Our study provided knowledge of the range of FRI for Provence, which is vital for the ecosystem management and sustainability. Provence is undoubtedly a fire hotspot for France (JRC-EFFIS, 2006), rather alike Corsica (mean FRI $=20$ years, Mouillot et al., 2003). We acknowledge that fire frequency depends critically on the area over which it was computed (Johnson and Gutsell 1994), thus interregional comparisons must be done cautiously. However, our FRI values for shrublands were intermediate between those of many MTEs including the Portuguese shrublands (12-16 yrs., Fernandes et al. 2010), South Africa fynbos (10-13 yrs., Van Wilgen et al. 2010) or grasslands (2-10 yrs., Archibald et al., 2011), and those of southern California chaparral (33-42 yrs., Moritz 2003; Moritz et al. 2004) or shrublands of south-western Australia (47 yrs., O'Donnell et al., 2011). Fire intervals in forests were much higher than those of ponderosa pine forests of Colorado (2-20 yrs., Grissino-Mayer et al., 2004) but much lower than those of Australian forests (310 years, (O'Donnell et al., 2011). They fall within the range for many MTEs (20-50 years, In Diaz-Delgado et al., 2004). Literature on natural fire rotation (NFR) period is scarce but we compared our data with those of neighbouring countries. The Maures massif had a short NFR value similar to that of Sierra de Gredos 
in Spain (64 years, Diaz-Delgado and Pons, 2001) while the Aix-Marseille area had a longer NFR value than that of the similar region of Catalonia (Spain, 133 years, Diaz-Delgado and Pons, 2001) but much lower than those of some areas or Portugal (maximum 762 years, Oliveira et al., 2011). Indeed, the authors have shown that the fire rotation period can range from 31 to 762 years according to the regions of Portugal.

Low age-dependency for most fuels of Provence suggested interplay between weather and fuels, according to Moritz et al. (2004a). Most fires occur during the dry and windy summer period (source: Prométhée database), indicating a harsh summer drought as a prominent driver of fires. The assumption that fuel age could limit reburning rests on the fact that fuel would be limited in a first step (i.e. insufficient to carry a new fire) then it would accumulate more or less continuously over time. Most of our fuels have short 'fuel limitation' stage: shrubs and grasses replenish in less than 1520 years even in the understory of pine or oak forests. Fire can thus ignite and spread in many fuels few years after a fire. An implication of these findings is that fuel management may not be sufficient to prevent fire recurrence, although it can reduce fire intensity and rate or spread, thus fire severity. Time-since-fire is not the predominant driver of new fires and cannot be the pivotal criterion for fuel management on landscape scale. This is confirmed by our flammability experiments and fire modelling exercises indicating that fire risk increases after fire until 20-30 years but tends to flatten out then to decrease in many forest fuels (Curt et al., 2011; Schaffhauser et al., 2011). Some studies have stated higher age-dependency of fire hazard for similar fuel types: Fernandes et al. (2010) have shown that Erica or Ulex shrublands and Pinus pinaster or Eucalyptus globulus forests of Portugal exhibit extreme fire frequency for Western Europe with Weibull's $c$ ranging from 2.6 to 4.8. They suggested that fires are weather-independent and that fuel management may be a priority to limit future fires. Such differences with our study can be explained by the fact that Portugal is the most fire-prone country in Europe whereas burned areas tend to decrease in France since the 1990's. Oliveira et al. (2011) found lower age dependency in regions of Portugal with high portions of shrublands, and higher age dependency for extensively forested regions. This difference with our results can result from the fact that areas with shrublands in Portugal are regularly burned then grazed and have small fires.

\subsection{Methodological considerations}

As our georeferenced fire database was unique for France, we tested the extent to which FRI and the Weibull parameters could change when censoring the fire data. Moritz et al. (2009) have explored the methodological limits and the sensitivity of the Weibull analysis to fire data, and stated that MEI and the $b$ and $c$ parameters are notably highly sensitive to censoring in fire intervals distribution. Our study confirmed that censoring data has strong effect on parameters estimates, in line with Oliveira et al. (2011) for Portuguese data. First, censored data tend to flatten out the Weibull density function and decrease the $c$ parameter, thus emphasizing the age-independency of fire hazard for most fuels (as stated by Moritz et al. 2009; Oliveira et al., 2011). Secondly, censored data revealed differences between the two areas, with stronger differences among fuels in the Aix-Marseille area. Although censored data are more restrictive, they provide calculations on time intervals really observed and thus provide a sound basis for the management of ecosystems. A typical feature of fires in Provence, especially in the Maures massif, is the existence of large fires burning frequently the same areas and thus generated similar time intervals for most fuels (see In Johnson and Gutsell 1994). This should increase because of the recent tendency to rare but large fires during exceptional conditions such as in 1990 and 2003 (Fig. 2).

\subsection{Conclusions}


In the study we have shown that two neighbouring areas with similar weather and roughly similar fuel types can have different fire intervals due to size, shape and connectivity of fuels in landscape, and the fire-fuel feedback. In the Maures massif, large fires propagate throughout extents of wildland and favour the expansion of maquis, which, in turn, favour new fires in the same location. This process has undoubtedly homogenized fire intervals across the landscape. In a more fragmented landscape with a large proportion of non-flammable fuels such as agriculture lands and orchards (AixMarseille area), fires propagate less easily through different fuel types, and fire intervals can be linked to fuel characteristics in a better way. This landscape contrast between the Maures massif and the Aix-Marseille area exist throughout the south-eastern France, where urbanized areas with smallgrained forests and wildland (such in AIXM) are side by side with areas dominated by large extents of forest and wildland (such in MAUR). Overall, this suggests that fires in Provence are predominantly triggered off by weather and human activity, and that fuel availability in the landscape is generally sufficient to let new fires propagate for some years (ca. 10 years for most fuels) after a previous event, depending upon the size and connectivity of fuels.

This study has implication for environmental management and fire prevention. First, it showed that a same fuel type may not face the same probability of burning again according to the area studied. Then, we showed that the hazard of burning varies weakly with the age of fuel (except for maquis). Thus, a systematic, intensive and costly management of all fuels would not automatically reduce fire risk and the probability of reburning in Provence, even if it is of interest to reduce fire intensity. The present policy of fire prevention uses intensive fuel management (shrub-clearing) only in areas at high risk, and a systematic surveillance of the most likely points of ignition (WUI, road corridors). When a fire occurs, the fire suppression services practice a rapid, hard-hitting initial attack on all ignitions, regardless of the fuel type and the weather conditions. However, Provence is likely to face large and intense fires (such as those of 1990 and 2003) in the future. These fires occur when the summers are exceptionally dry and when fire suppression capacities are overwhelmed. They paradoxically result from the efficient policy of fire prevention and fire fighting set up during the 1980's, which has favoured fuel accumulation in shrublands and many pine forests (Sande Silva et al., 2010). In this context, the distribution of low-flammable fuel types such as mature oak forests or immature shrublands with low fuel biomass could be crucial to wildland conservation and to limit future fires or fire damage in the context of forecasted weather conditions (Moreira et al., 2011). 
Author-produced version of the article published in Journal of Environmental Management, 2013, 117, 150-161 Original publication available at http://www.sciencedirect.com/

doi : 10.1016/j.jenvman.2012.12.006

\section{Figures Captions}

Figure 1. Maps of burned areas and fire frequency (1960-2010) for: A. AIXM (Aix-Marseille area). B. MAUR (Maures massif). The contour of each study area is drawn in light grey.

Figure 2. Burned area and number of fires larger than 3 ha (1960-2010) for AIXM (Aix-Marseille area, 510,593 ha) and MAUR (Maures massif, 145,686 ha).

Figure 3. Main characteristics of the fuel groups and the two study areas (AIXM: Aix-Marseille area; MAUR: Maures massif). The overstory covering is the percentage of covering by the tree canopy (height of trees $>10 \mathrm{~m}$ ). The understory covering is the percentage of covering by shrubs (height $<1$ $\mathrm{m})$. The fuel bed depth is the height of surface fuels contained in the combustion zone of a spreading fire front, including notably low branches, shrubs, and grasses. The 1-h fuel load is the dry biomass of fine fuels (diameter $<6 \mathrm{~mm}$ ). Large grey bars are mean values, and small black bars are $95 \%$ confidence intervals. Different letter for a same variable but different study indicate a statistically different difference using the Tukey HSD test (with $\alpha<0.05$ ). Sample size is 8 (SHRUB), 9 (PINE), 12 (MIXED) and 10 (OAK) in AIXM, and 31 (SHRUB), 20 (PINE), 19 (MIXED) and 32 (OAK) in MAUR

Figure 4. Fuel contagion index for AIXM (Aix-Marseille area) and MAUR (Maures massif). The contagion index has been computed for shrublands, forests, and the whole landscape within each area. High values (close to 100) indicate that fires may theoretically propagate easily whereas low values (close to 0 ) indicate low probability of fire propagation

Figure 5. Hazard of burning for the four main fuel groups in AIXM (Aix-Marseille area) and MAUR (Maures massif). Values were computed using the Weibull model with censored values. For complete data see Appendices $2 \mathrm{~A}$ and $2 \mathrm{~B}$

Figure 1. A

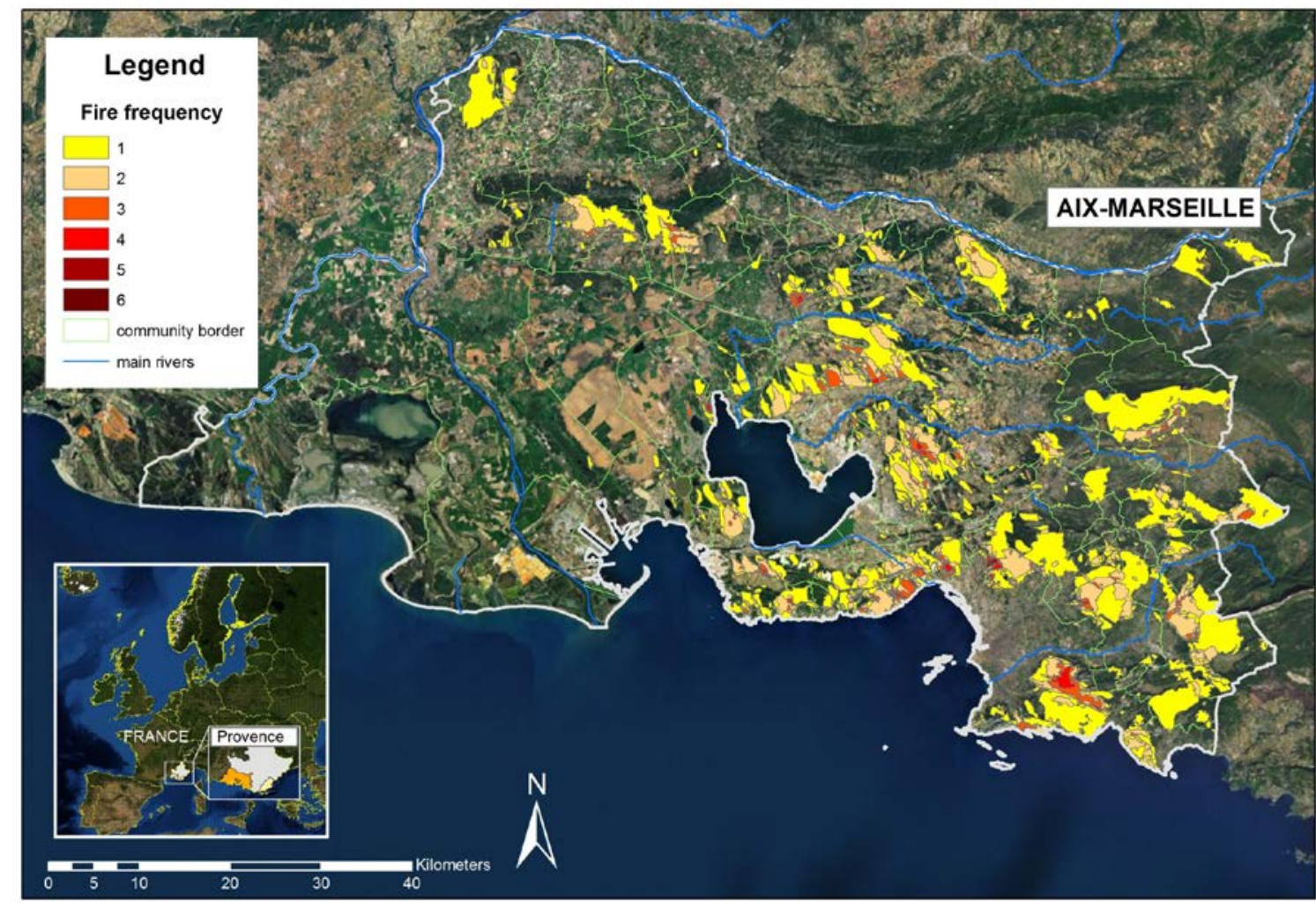


Author-produced version of the article published in Journal of Environmental Management, 2013, 117, 150-161 Original publication available at http://www.sciencedirect.com/

doi : 10.1016/j.jenvman.2012.12.006

Figure 1. B

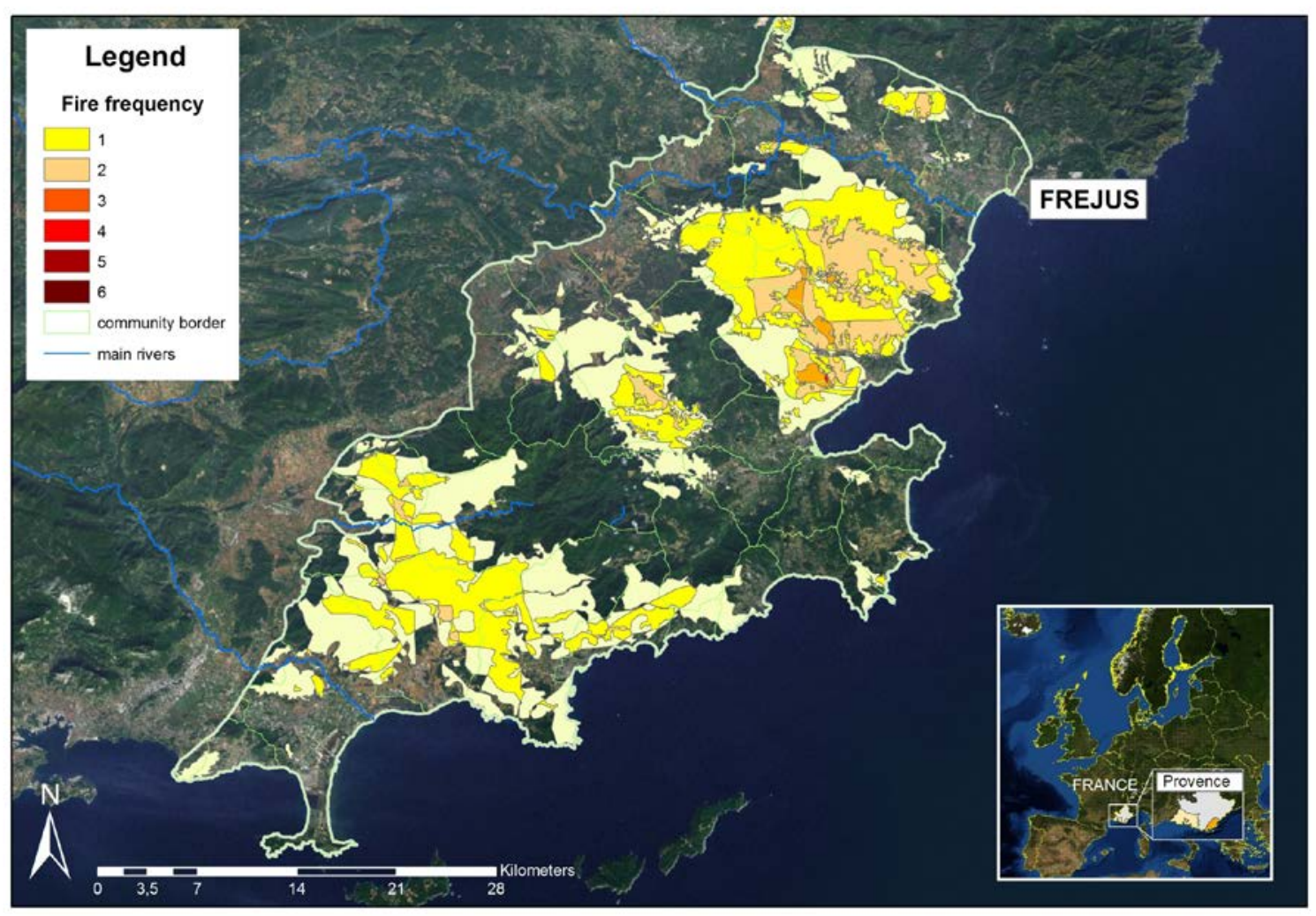


Author-produced version of the article published in Journal of Environmental Management, 2013, 117, 150-161 Original publication available at http://www.sciencedirect.com/

doi : 10.1016/j.jenvman.2012.12.006

Figure 2
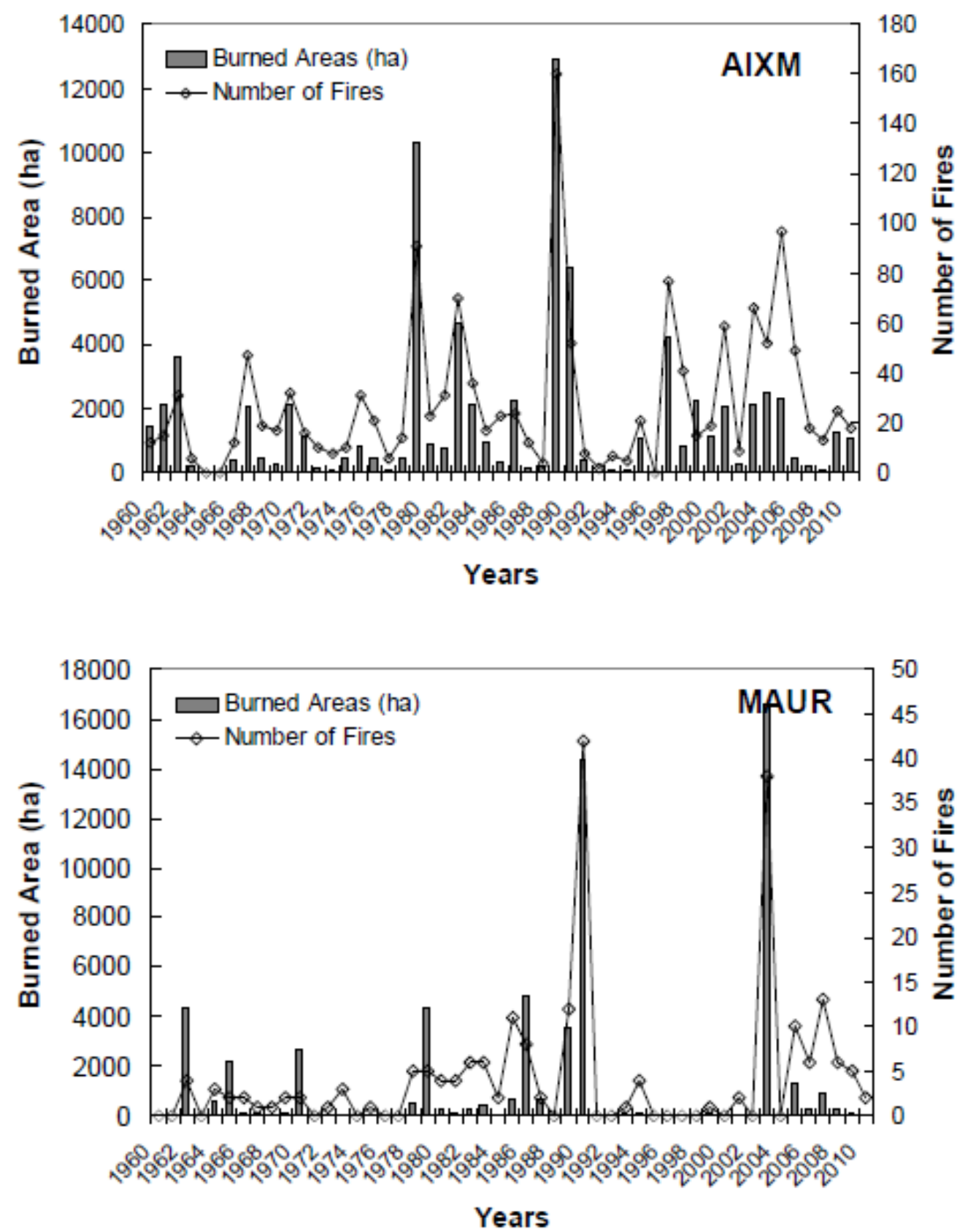
Author-produced version of the article published in Journal of Environmental Management, 2013, 117, 150-161 Original publication available at http://www.sciencedirect.com/ doi : 10.1016/j.jenvman.2012.12.006

Figure 3
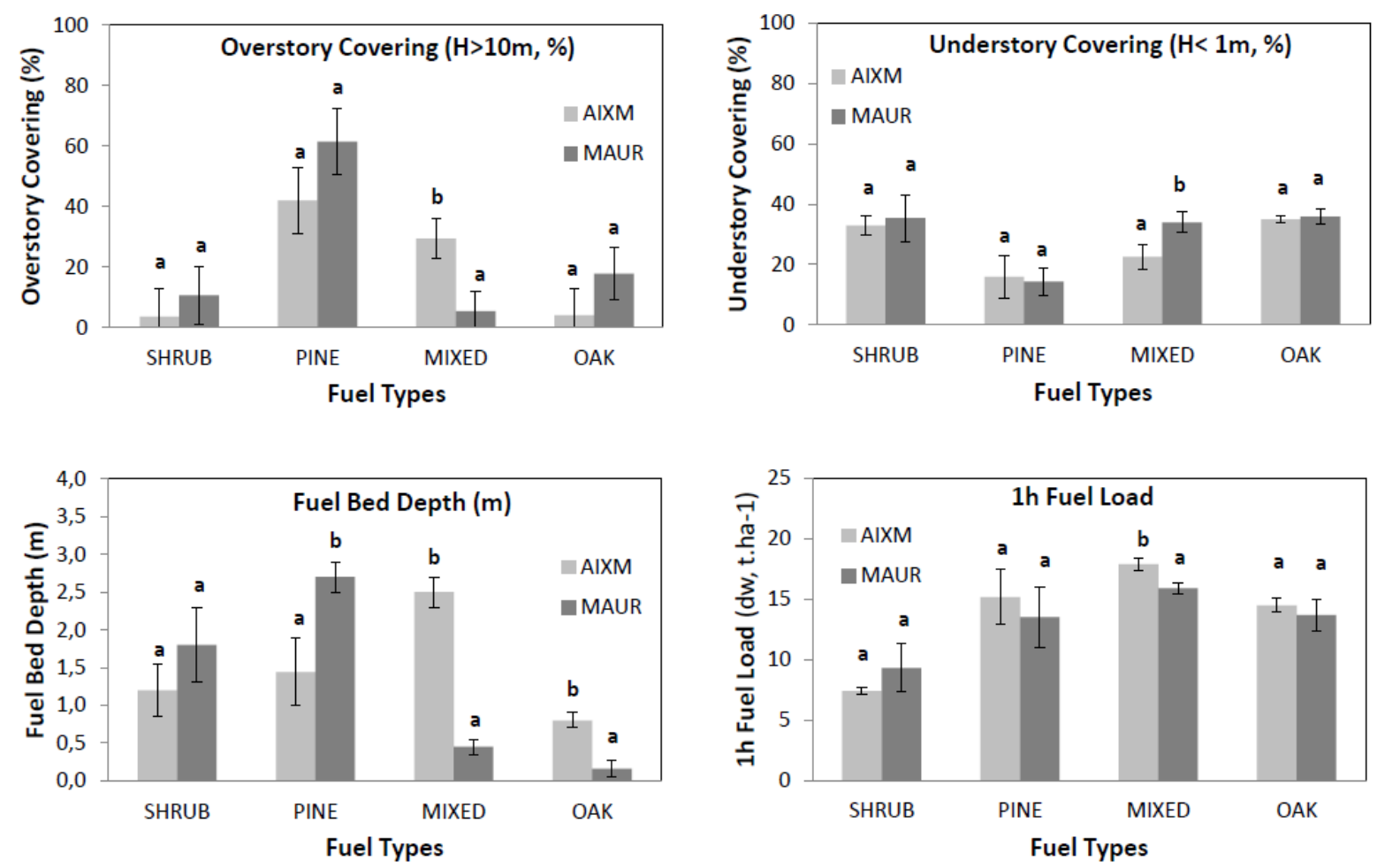
Author-produced version of the article published in Journal of Environmental Management, 2013, 117, 150-161 Original publication available at http://www.sciencedirect.com/ doi : 10.1016/j.jenvman.2012.12.006

Figure 4

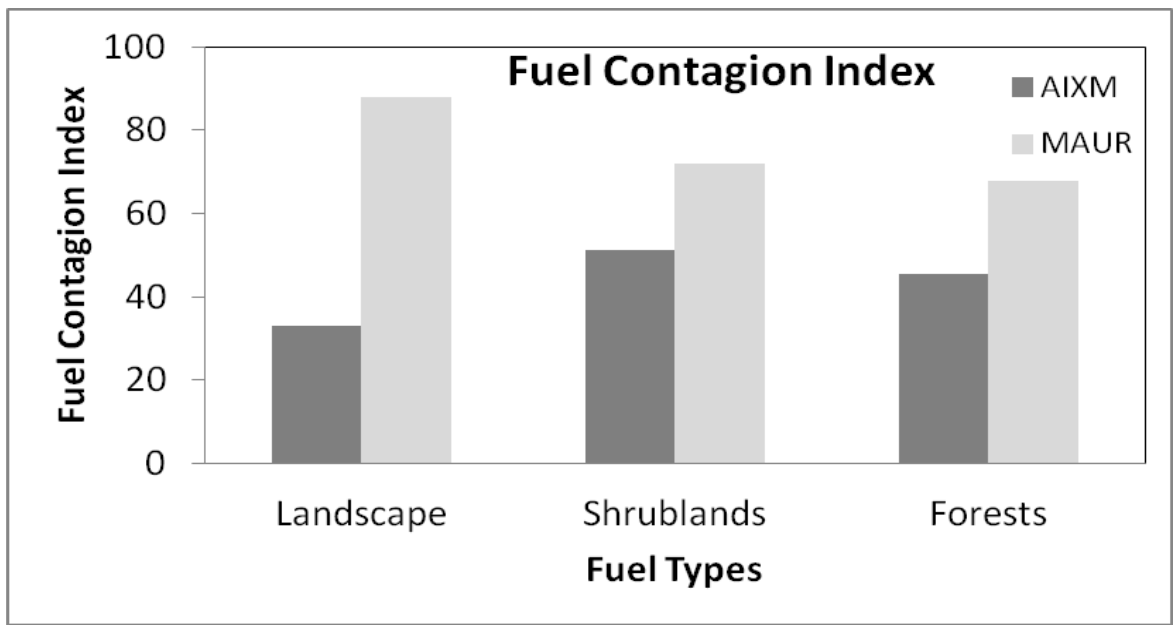


Author-produced version of the article published in Journal of Environmental Management, 2013, 117, 150-161 Original publication available at http://www.sciencedirect.com/

doi : 10.1016/j.jenvman.2012.12.006

Figure 5
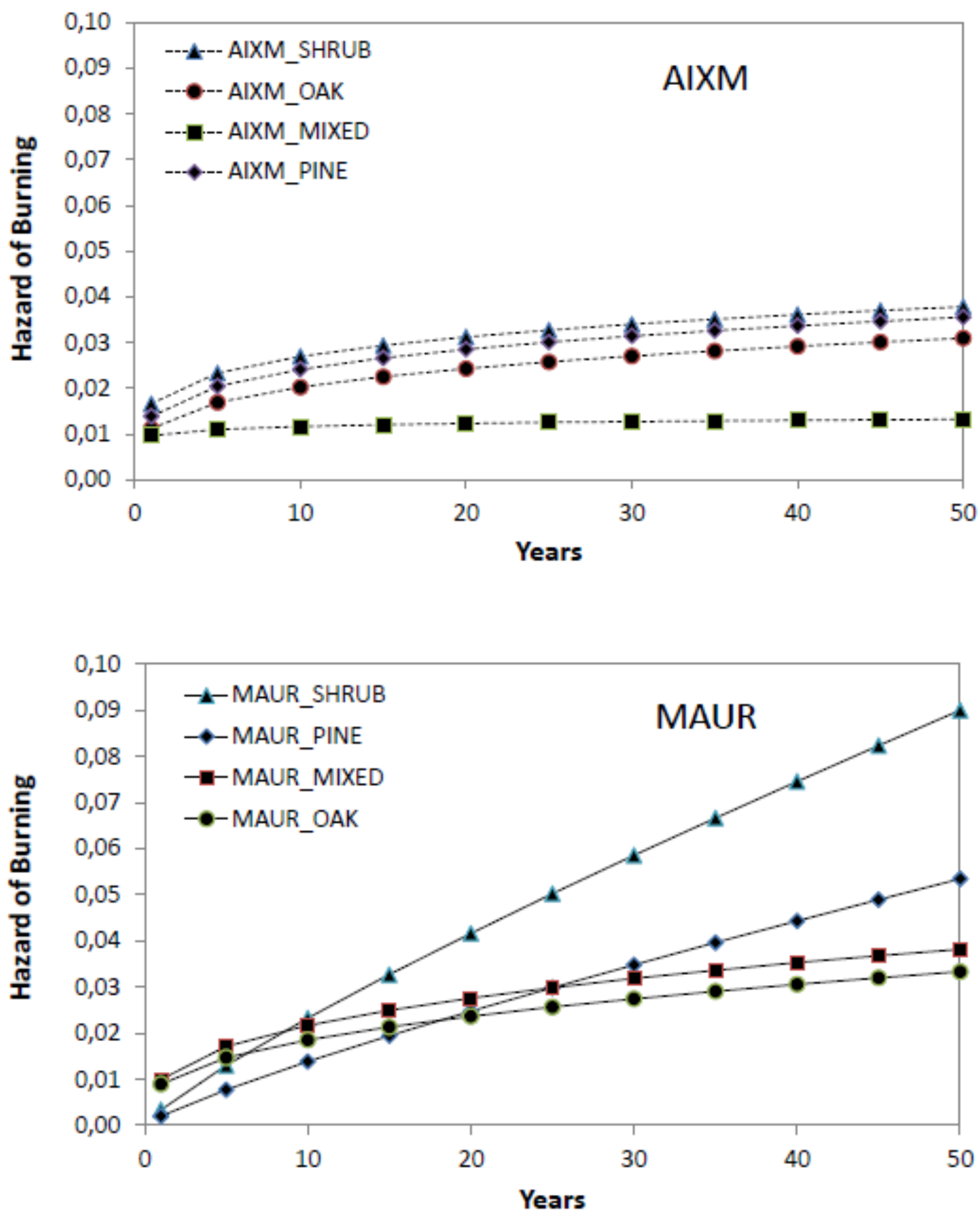
Table 1. Main spatial characteristics of fires and fuel types in the study areas, for fires larger than 3 ha (1960-2010). Different letters indicate statistically different values (Mann-Whitney test; Wilcoxon, $\mathrm{P}<0.05$ )

\begin{tabular}{lcc}
\hline \multicolumn{1}{c}{ Fire Characteristics } & Aix-Marseille Area (AIXM) & Maures Area (MAUR) \\
\hline \multicolumn{1}{c}{ Fire Patterns } & & \\
\hline Number of fires & 1,451 & 217 \\
Fire size (mean \pm SE, ha) & $56 \pm 200 a$ & $292 \pm 717 b$ \\
Number of fires per a year (mean \pm SE) & $28 \pm 30 b$ & $4 \pm 8 a$ \\
Area burned annually (mean \pm SE, ha) & $1,592 \pm 2,452 a$ & $1,177 \pm 3,170 a$ \\
Percent area burned annually (\%) & 0.31 & 0.81 \\
Cumulated area burned (ha) & 104,171 & 112,377 \\
Total extension of the area burned (ha) & 78,860 & 59,606 \\
Percentage area burned at least once (\%) & 14.7 & 40.9 \\
Fraction burned 1, 2, 3, 4 and 5 times ${ }^{5}$ & $71.8,22.6,4.5,1.0,0.1$ & $60.0,30.5,8.7,0.9,0.002$ \\
Fire Cycle or Natural Fire Rotation (years) & 235 & 62 \\
& & \\
\hline \multicolumn{1}{c}{ Fuel and Landscape Patterns } & & 145,686 \\
\hline Size of the study area (ha) & 510,593 & 2,966 \\
Number of fuel patches & 9,594 & $49 \pm 402 a$ \\
Mean fuel patch size (ha) & $55 \pm 971 a$ & $5 a$ \\
Area Weighted Mean Shape Index & $7 b$ & $169 a$ \\
Mean perimeter/area ratio per fuel patch & $208 b$ & $50 \pm 27 b$ \\
Mean shrubland patch size (ha) & $21 \pm 39 a$ & $37 \pm 76 a$ \\
Mean forest patch size (ha) & $26 \pm 99 a$ & 2133 \\
Mesh (shrublands) & 315 & 413 \\
Mesh (forests) & 283 & 165 \\
Split (shrublands) & 2890 & 867 \\
Split (forests) & 3499 & 88 \\
Fuel contagion index (whole landscape) & 33 & 71.9 \\
Fuel contagion index (shrublands) & 51.3 & 67.9 \\
Fuel contagion index (forests) & 45.3 & \\
& &
\end{tabular}

\footnotetext{
${ }^{\S}$ This percentage was calculated on the total area burned

*The fractions were computed among the area burned at least once during the 1960-2010 period
} 
Author-produced version of the article published in Journal of Environmental Management, $2013,117,150-161$

Original publication available at http://www.sciencedirect.com/

doi : 10.1016/j.jenvman.2012.12.006

Appendix 1A. Main characteristics of the fuel types for the Provence area (AIXM, limestone-derived soils).

\begin{tabular}{|c|c|c|c|c|c|}
\hline Vegetation Type & Dominant Species & $\begin{array}{c}\text { Overstory } \\
\text { Covering }{ }^{\S} \\
(\mathrm{H}>10 \mathrm{~m} ; \%)\end{array}$ & $\begin{array}{l}\text { Understory } \\
\text { Covering }{ }^{\S} \\
(\mathrm{H}<1 \mathrm{~m}, \%)\end{array}$ & $\begin{array}{l}\text { Fuel Bed } \\
\text { Depth }(m)\end{array}$ & $\begin{array}{l}\text { 1h Fuel Load } \\
\left(\mathrm{dw}, \mathrm{t}^{-1} \mathrm{a}^{-1}\right)\end{array}$ \\
\hline Garrigues & $\begin{array}{l}\text { Quercus coccifera, Juniperus oxycedrus, Ulex parviflorus, } \\
\text { Cistus spp., Rosmarinus officinalis, Brachypodium retusum }\end{array}$ & 4.0 & 35.0 & 1.2 & 7.4 \\
\hline Pine forests & Pinus halepensis, Phyllirea angustifolia, Quercus coccifera & 44.0 & 33.0 & 1.0 & 16.4 \\
\hline Mixed pine-oak forests & Pinus halepensis, Quercus pubescens, Quercus ilex & 35.0 & 23.0 & 2.5 & 17.9 \\
\hline Mixed oak forests & Quercus pubescens, Quercus ilex, Ulex parviflorus & 42.0 & 10.0 & 0.8 & 15.5 \\
\hline Spontaneous afforestation & Pinus halepensis & 13.0 & 26.0 & 3.0 & 6.7 \\
\hline Sparse woodlands & Pinus halepensis, Quercus spp., Rosaceae & 12.0 & 33.0 & 1.5 & 7.0 \\
\hline Vegetation WUI & All species (pines, oaks) with shrub-cleared understory & 78.0 & 8.0 & 1.2 & 12.8 \\
\hline Road corridors & Graminoids and dicots, Quercus coccifera & 0.0 & 13.0 & 0.5 & 8.0 \\
\hline
\end{tabular}

${ }^{\S}$ Standard errors were not computed for covering values

Appendix 1B. Main characteristics of the fuel types for the Provence area (MAUR, siliceous soils).

\begin{tabular}{|c|c|c|c|c|c|}
\hline Vegetation Type & Dominant Species & $\begin{array}{c}\text { Overstory } \\
\text { Covering } \\
(\mathrm{H}>10 \mathrm{~m} ; \%)\end{array}$ & $\begin{array}{c}\text { Understory } \\
\text { Covering } \\
(\mathrm{H}<1 \mathrm{~m})(\%)\end{array}$ & $\begin{array}{l}\text { Fuel Bed } \\
\text { Depth }(\mathrm{m})\end{array}$ & $\begin{array}{l}\text { 1-h Fuel Load } \\
\left(\mathrm{dw}, \mathrm{t}^{-h^{-1}}\right)\end{array}$ \\
\hline Maquis & Erica arborea, Cistus spp., Calycotome spinosa & $0.5 \pm 1.0$ & $34.7 \pm 6.1$ & 0.8 & 7.5 \\
\hline Maquis with cork oak & $\begin{array}{l}\text { Quercus suber, Arbutus unedo, Erica arborea, Cistus spp., } \\
\text { Calycotome spinosa }\end{array}$ & $27.0 \pm 5.0$ & $37.0 \pm 10.1$ & 1.8 & 9.0 \\
\hline $\begin{array}{l}\text { Maquis with mixed oak } \\
\text { woodlands }\end{array}$ & $\begin{array}{c}\text { Calycotome spinosa, Cistus spp., Quercus suber, } Q . \text { ilex, } Q . \\
\text { pubescens, }\end{array}$ & $26.0 \pm 4.2$ & $36.1 \pm 9.0$ & 2.8 & 11.5 \\
\hline Maquis with pine & Pinus pinaster, Cistus spp., Calycotome spinosa & $24.0 \pm 5.3$ & $34.0 \pm 10.4$ & 2.7 & 11.5 \\
\hline Cork oak forests & Quercus suber, Brachypodium retusum, Calycotome spinosa & $49.0 \pm 5.2$ & $18.3 \pm 6.0$ & 0.3 & 14.6 \\
\hline Mixed pine-oak forests & Pinus pinaster, Quercus ilex, Q. pubescens, Q. suber & $70.6 \pm 6.5$ & $12.4 \pm 2.3$ & 0.1 & 15.9 \\
\hline & Quercus ilex, Q. pubescens, Q. suber, Brachypodium & $75 \pm 2.3$ & $8.3 \pm 3.3$ & 0.1 & 16.0 \\
\hline
\end{tabular}


Author-produced version of the article published in Journal of Environmental Management, 2013, 117, 150-161

Original publication available at http://www.sciencedirect.com/

doi : 10.1016/j.jenvman.2012.12.006

Appendix 2A. Weibull model parameters $a$ and $b$ for the hazard of burning function, mean fire intervals (FRI), and median fire-free intervals (MEI) for the fuel types of the Aix-Marseille area (AIXM, limestone-derived soils). Different letters for mean fire intervals indicate statistically significant differences ( $<$ $0.001)$

\begin{tabular}{|c|c|c|c|c|c|c|c|c|}
\hline \multirow{2}{*}{ Fuel Types } & \multirow{2}{*}{$\begin{array}{l}\text { Area } \\
\text { (ha) }\end{array}$} & \multirow{2}{*}{$\begin{array}{c}\text { Mean fire interval } \\
\text { FRI (mean } \pm \text { SE) }\end{array}$} & \multicolumn{3}{|c|}{ Uncensored } & \multicolumn{3}{|c|}{ Censored } \\
\hline & & & MEI (years) & $b$ & c & MEI (years) & $b$ & c \\
\hline Garrigues & 50,076 & $18.3 \pm 12.2 \mathrm{a}$ & $17.2 \mathrm{a}$ & 20.2 & 1.87 & $23.5 \mathrm{a}$ & 30.5 & 1.21 \\
\hline Pine forests & 13,941 & $19.6 \pm 12.9 \mathrm{ab}$ & $17.5 \mathrm{a}$ & 21.8 & 1.53 & $34.8 \mathrm{~b}$ & 45.9 & 1.24 \\
\hline Mixed pine-oak forests & 12,195 & $23.6 \pm 12.2 \mathrm{bc}$ & $22.6 \mathrm{~b}$ & 26.5 & 1.99 & $56.2 \mathrm{c}$ & 78.5 & 1.08 \\
\hline Mixed oak forests & 10,521 & $24.4 \pm 11.8$ bc & $21.9 a b$ & 25.2 & 1.94 & $62.2 \mathrm{~d}$ & 85.4 & 1.08 \\
\hline Spontaneous afforestation & 8,242 & $19.9 \pm 11.2 \mathrm{ab}$ & $19.5 \mathrm{~b}$ & 22.3 & 1.81 & $33.2 \mathrm{~b}$ & 43.8 & 1.28 \\
\hline Sparse woodlands & 5,101 & $20.7 \pm 12.4 \mathrm{ab}$ & $19.3 \mathrm{~b}$ & 23.2 & 1.70 & $29.9 \mathrm{~b}$ & 37.4 & 1.24 \\
\hline Vegetation WUI & 3,517 & $20.8 \pm 12.5 a b$ & $19.2 \mathrm{~b}$ & 23.3 & 1.67 & $52.5 \mathrm{c}$ & 70.4 & 1.25 \\
\hline Road corridors & 578 & $22.2 \pm 14.4 \mathrm{~b}$ & $19.5 \mathrm{~b}$ & 24.5 & 1.49 & $30.4 \mathrm{~b}$ & 42.1 & 1.36 \\
\hline Total Area & 104,171 & $20.3 \pm 12.6$ & 18.2 & 22.6 & 1.61 & 33.3 & 44.5 & 1.20 \\
\hline
\end{tabular}

Appendix 2B. Weibull model parameters $a$ and $b$ for the hazard of burning function, mean fire intervals (FRI), and median fire-free intervals (MEI) for the fuel types of the Maures massif (MAUR, siliceous soils). Different letters for mean fire intervals indicate statistically significant differences ( $<$ < 0.001 )

\begin{tabular}{|c|c|c|c|c|c|c|c|c|}
\hline \multirow{2}{*}{ Fuel Types } & \multirow[t]{2}{*}{ Area (ha) } & \multirow{2}{*}{$\begin{array}{l}\text { Mean fire interval } \\
\text { FRI (mean } \pm \text { SE) }\end{array}$} & \multicolumn{3}{|c|}{ Uncensored } & \multicolumn{3}{|c|}{ Censored } \\
\hline & & & MEI (years) & $b$ & $c$ & MEI (years) & $b$ & $c$ \\
\hline Maquis & 18,048 & $22.2 \pm 10.5 a$ & $20.2 \mathrm{a}$ & 24.8 & 2.12 & $21.8 \mathrm{a}$ & 26.8 & 1.88 \\
\hline Maquis with cork oak & 28,599 & $21.4 \pm 11.4 \mathrm{a}$ & $19.5 \mathrm{a}$ & 24.0 & 1.88 & $28.5 \mathrm{~b}$ & 34.7 & 1.79 \\
\hline Maquis with mixed oak woodlands & 2,971 & $22.2 \pm 16.5 a$ & $20.4 \mathrm{a}$ & 26.0 & 1.54 & $22.8 \mathrm{a}$ & 27.8 & 1.83 \\
\hline Maquis with pine & 7,941 & $24.0 \pm 11.5 a b$ & $23.3 \mathrm{~b}$ & 27.2 & 2.23 & $32.0 \mathrm{~b}$ & 38.7 & 1.84 \\
\hline Cork oak forests & 27,961 & $28.8 \pm 8.5 c$ & $25.5 \mathrm{c}$ & 21.1 & 1.83 & $35.0 \mathrm{c}$ & 28.8 & 1.37 \\
\hline Mixed pine-oak forests & 15,573 & $28.0 \pm 8.2 c$ & $25.1 \mathrm{c}$ & 26.3 & 1.65 & $29.9 \mathrm{~b}$ & 38.5 & 1.27 \\
\hline
\end{tabular}


Author-produced version of the article published in Journal of Environmental Management, 2013, $117,150-161$

Original publication available at http://www.sciencedirect.com/

doi : 10.1016/j.jenvman.2012.12.006

\begin{tabular}{lcccccrrr} 
Mixed oak forests & 8,941 & $27.4 \pm 14.7 \mathrm{c}$ & $24.8 \mathrm{bc}$ & 23.8 & 1.57 & $28.9 \mathrm{~b}$ & 37.9 & 1.19 \\
Chestnut forests & 940 & $31.3 \pm 11.5 \mathrm{~d}$ & $23.1 \mathrm{~b}$ & 24.1 & 1.26 & $25.0 \mathrm{ab}$ & 32.3 & 1.23 \\
Vegetation WUI & 1,403 & $27.2 \pm 15.9 \mathrm{c}$ & $24.4 \mathrm{bc}$ & 23.9 & 1.41 & $24.1 \mathrm{ab}$ & 30.7 & 1.29 \\
\hline Total Area & 112,377 & $22.2 \pm 12.3$ & 20.2 & 24.9 & 1.82 & 30.0 & 38.1 & 1.53 \\
\hline
\end{tabular}


Author-produced version of the article published in Journal of Environmental Management, 2013, 117, 150-161 Original publication available at http://www.sciencedirect.com/

doi : 10.1016/j.jenvman.2012.12.006

\section{Acknowledgments}

We greatly acknowledge colleagues from Cemagref, National Forest Service and Regional Forest Service (Provence Alpes Côte-d'Azur Region) for their help building the fire database. 


\section{References}

Acácio, V., Holmgren, M., Rego, F., Moreira, F., Mohren, G.M.J., 2009 Are drought and wildfires turning Mediterranean cork oak forests into persistent shrublands? Agroforestry Systems 76, 389-400.

Agee, J., 1993 Fire ecology of Pacific Northwest forests Island Press, Washington, D.C.

Alessio, G.A., Penuelas, J., De Lillis, M., Llusia, J., 2008 Implications of foliar terpene content and hydration on leaf flammability of Quercus ilex and Pinus halepensis Plant Biology 10, 123-128.

Allen, C.D., Savage, M., Falk, D.A., Suckling, K.F., Swetnam, T.W., Schulke, T., Stacey, P.B., Morgan, P., Hoffman, M., Klingel, J.T., 2002 Ecological restoration of Southwestern ponderosa pine ecosystems: A broad perspective Ecological Applications 12, 1418-1433.

Archibald, S., Scholes, R., Roy, D., Roberts, G., Boschetti, L., 2011 Southern African fire regimes as revealed by remote sensing International Journal of Wildland Fire 19, 861-878.

Baeza, M.J., Raventos, J., Escarre, A., Vallejo, V.R., 2006 Fire risk and vegetation structural dynamics in Mediterranean shrubland Plant Ecology 187, 189-201.

Barbéro, M., Loisel, R., Quézel, P., Richardson, D., Romane, F., 2000 Pines of the Mediterranean basin In Richardson DM (Ed.). Ecology and Biogeography of Pinus. Cambridge University Press. 153-182.

Burrows, N.D., 2008 Linking fire ecology and fire management in south-west Australian forest landscapes Forest Ecology and Management 255, 2394-2406.

Crow, T.R., Johnson, W.C., Adkisson, C.S., 1994 Fire and recruitment of Quercus in Postagricultural field The American Midland Naturalist 131, 84-97.

Curt, T., Adra, W., Borgniet, L., 2009 Fire-driven oak regeneration in French Mediterranean ecosystems Forest Ecology and Management 258, 2127-2135.

Curt, T., Delcros, P., 2010 Managing road corridors to limit fire hazard. A simulation approach in southern France Ecological Engineering 36, 457-465.

Curt, T., Schaffhauser, A., Borgniet, L., Dumas, C., Esteve, R., Ganteaume, A., Jappiot, M., Martin, W., N'Diaye, A., Poilvet, B., 2011 Litter flammability in oak woodlands and shrublands of southeastern France Forest Ecology and Management 261, 2214-2222.

De Lillis, M., Bianco, P.M., Loreto, F., 2009 The influence of leaf water content and isoprenoids on flammability of some Mediterranean woody species International Journal of Wildland Fire 18, 203-212.

Diaz-Delgado, R., Lloret, F., Pons, X., 2004 Spatial patterns of fire occurrence in Catalonia, NE, Spain Landscape Ecology 19, 731-745.

Diaz-Delgado, R., Pons, X., 2001 Spatial patterns of forest fires in Catalonia (NE of Spain) along the period 19751995 - Analysis of vegetation recovery after fire Forest Ecology and Management 147, 67-74.

Dimitrakopoulos, A.P., Mitsopoulos, I.D., Raptis, D.I., 2007 Nomographs for predicting crown fire initiation in Aleppo pine (Pinus halepensis Mill.) forests European Journal of Forest Research 126, 555-561.

Dodson, B., 2006 The Weibull Analysis Handbook American Society for Quality, Quality Press, Milwaukee 2nd Edition, 167 pp.,

Eugenio, M., Lloret, F., Alcaniz, J.M., 2006 Regional patterns of fire recurrence effects on calcareous soils of Mediterranean Pinus halepensis communities Forest Ecology and Management 221, 313-318.

Fernandes, P., 2009 Combining forest structure data and fuel modelling to classify fire hazard in Portugal Annals of Forest Science 66, 415-424.

Fernandes, P., Loureiro, C., Margalhaes, M., Ferreira, P., 2010 Testing the fire paradox: is fire incidence in Portugal affected by fuel age? In: Proc. IUFRO Landscape Working Group International Conference, September 2127, Bragança (Portugal) 705-710.

Fernandes, P.M., Botelho, H.S., 2003 A review of prescribed burning effectiveness in fire hazard reduction International Journal of Wildland Fire 12, 117-128.

Fernandes, P.M., Rigolot, E., 2007 The fire ecology and management of maritime pine (Pinus pinaster Ait.) Forest Ecology and Management 241, 1-13.

Fernandes, P.M., Vega, J.A., Jimenez, E., Rigolot, E., 2008 Fire resistance of European pines Forest Ecology and Management 256, 246-255.

Ganteaume, A., Jappiot, M., Lampin-Maillet, C., Curt, T., Borgniet, L., 2009 Fuel characterization and effects of wildfire recurrence on vegetation structure on limestone soils in southeastern France Forest Ecology and Management 258, S15-S23.

Gill, A.M., 1975 Fire and the Australian flora. A review Australian Forestry 38, 4-25.

Grissino-Mayer, H.D., 1999 Modeling fire interval data from the American Southwest with the Weibull distribution International Journal of Wildland Fire 9, 37-50. 
Grissino-Mayer, H.D., Romme, W.H., Floyd, M.L., Hanna, D.D., 2004 Climatic and human influences on fire regimes of the southern San Juan Mountains, Colorado, USA Ecology 85, 1708-1724.

Gu, J., Li, X., Huang, C., Okin, G.S., 2009 A simplified data assimilation method for reconstructing time-series MODIS NDVI data Advances in Space Research 501-509.

Heinselman, M., 1973 Fire virgin forests of four sites in the Boundary Waters Canoe Area, Minnesota Quaternary Research 329-382.

Johnson, E., Gutsell, S., 1994 Fire frequency models, Methods and Interpretation Advances Ecol. Res. 25, $239-287$.

Johnson, E.A., Miyanishi, K., O'Brien, N., 1999 Long-term reconstruction of the fire season in the mixedwood boreal forest of Western Canada Canadian Journal of Botany-Revue Canadienne De Botanique 77, 11851188.

JRC-EFFIS, 2006 Forest fires in Europe. Report $N^{\circ} 7$ Land Management and Natural Hazards Unit. http://effis.jrc.ec.europa.eu/ 79 pp.

Keeley, J., Bond, W., Bradstock, R., Pausas, J., Rundel, P., 2012 Fire in Mediterranean Ecosystems. Ecology, Evolution and Management Cambridge University Press 450 pp.,

Keeley, J.E., Fotheringham, C.J., Morais, M., 1999 Reexamining fire suppression impacts on brushland fire regimes Science 284, 1829-1832.

Keeley, J.E., Zedler, P.H., 2009 Large, high-intensity fire events in southern California shrublands: debunking the fine-grain age patch model Ecological Applications 19, 69-94.

Lampin-Maillet, C., Mantzavelas, A., Galiana, L., Jappiot, M., Long, M., Herrero, G., Karlsson, O., Iossifina, A., Thalia, L., Thanassis, P., 2010 Wildland urban interfaces, fire behaviour and vulnerability: characterization, mapping and assessment. Research Report - European Forest Institute (EFI). 23, 71-92.

Lawless, J., 2003 Statistical models and methods of lifetime data Wiley, Hoboken

Lloret, F., Calvo, E, Pons, X, Diaz-Delgado, R, 2002 Wildfires and landscape patterns in the Eastern Iberian Peninsula Landscape Ecology 745-759.

Martin, R., Sapsis, D., 1992 Fires as agents of biodiversity: Pyrodiversity promotes biodiversity In: Proceedings Symposium Biodiversity of Northern California, Univ. California, Berkeley, pp. 150-157

McGarigal, K., Cushman, S., Neel, M., Ene, E., 2002 FRAGSTATS: Spatial Pattern Analysis Program for Categorical Maps. Computer software program produced by the authors at the University of Massachusetts, Amherst. http://www.umass.edu/landeco/research/fragstats/fragstats.html

Mermoz, M., Kitzberger, T., Veblen, T.T., 2005 Landscape influences on occurrence and spread of wildfires in Patagonian forests and shrublands Ecology 86, 2705-2715.

Minnich, R., Chou, YH, 1997 Wildland fire patch dynamics in the chaparral of southern California and northern Baja California Int. J. Wildland Fire 221-248.

Minnich, R.A., 1983 Fire mosaics in Southern-California and Northern Baja California Science 219, 1287-1294.

Minnich, R.A., Chou, Y.H., 1997 Wildland fire patch dynamics in the chaparral of southern California and northern Baja California International Journal of Wildland Fire 7, 221-248.

Moreira, F., Rego, F.C., Ferreira, P.G., 2001 Temporal (1958-1995) pattern of change in a cultural landscape of northwestern Portugal: implications for fire occurrence Landscape Ecology 16, 557-567.

Moreira, F., Viedma, O., Arianoutsou, M., Curt, T., Koutsias, N., Rigolot, E., Barbati, A., Corona, P., Vaz, P., Xanthopoulos, G., Mouillot, F., Bilgili, E., 2011 Landscape - wildfire interactions in southern Europe: Implications for landscape management Journal of Environmental Management 92, 2389-2402.

Moreno, J., Oechel, W., 1994 The Role of Fire in Mediterranean-Type Ecosystems Springer Verlag (Ecological Studies v 107) 201 pp.

Moritz, M., Keeley, J., Johnson, E., Schaffner, A., 2004a Testing a basic assumption of shrubland fire management: how important is fuel age? Frontiers in Ecol. and Environm. 2, 67-72.

Moritz, M., Moody, T., Miles, L., Smith, M., Valpine, P., 2009 The fire frequency analysis branch of the pyrostatistics tree: sampling decisions and censoring in fire interval data Environmental and Ecological Statistics 16, 271-289.

Moritz, M.A., 2003 Spatiotemporal analysis of controls on shrubland fire regimes: Age dependency and fire hazard Ecology 84, 351-361.

Moritz, M.A., Keeley, J.E., Johnson, E.A., Schaffner, A.A., 2004b Testing a basic assumption of shrubland fire management: how important is fuel age? Frontiers in Ecology and the Environment 2, 67-72.

Mouillot, F., Rambal, S., Joffre, R., 2002 Simulating climate change impacts on fire frequency and vegetation dynamics in a Mediterranean-type ecosystem Global Change Biology 8, 423-437.

Mouillot, F., Ratte, J.P., Joffre, R., Moreno, J.M., Rambal, S., 2003 Some determinants of the spatio-temporal fire cycle in a mediterranean landscape (Corsica, France) Landscape Ecology 18, 665-674. 
Myers, N., Mittermeier, R.A., Mittermeier, C.G., da Fonseca, G.A.B., Kent, J., 2000 Biodiversity hotspots for conservation priorities Nature 403, 853-858.

O'Donnell, A.J., Boer, M.M., McCaw, W.L., Grierson, P.F., 2011 Vegetation and landscape connectivity control wildfire intervals in unmanaged semi-arid shrublands and woodlands in Australia Journal of Biogeography 38, 112-124.

Oliveira, S., Pereira, J., Carreiras, J., 2011 Fire frequency analysis in Portugal (1975-2005), using Landsat-based burnt area maps International Journal of Wildland Fire 21, 48-60.

Pausas, J.G., 2006 Simulating Mediterranean landscape pattern and vegetation dynamics under different fire regimes Plant Ecology 187, 249-259.

Pausas, J.G., Llovet, J., Rodrigo, A., Vallejo, R., 2008 Are wildfires a disaster in the Mediterranean basin? A review International Journal of Wildland Fire 17, 713-723.

Polakow, D.A., Dunne, T.T., 1999 Modelling fire-return interval T: stochasticity and censoring in the twoparameter Weibull model Ecological Modelling 121, 79-102.

Pyne, S., Andrews, P., Laven, R., 1996 Introdution to wildland fire J. Wiley and Sons, New York (2nd Ed.), 769 pp.

Quézel, P., Médail, F., 2003 Ecologie et biogéographie des forêts du bassin méditerranéen. Ecology and Biogeography of the forests of the Mediterranean basin Elsevier Ed., Paris $571 \mathrm{pp}$.

R Development Core Team, 2011 R: A language and environment for statistical computing, reference index version v. 2.14.1 R Foundation for Statistical Computing, Vienna, Austria

Rigolot, E., 2004 Predicting postfire mortality of Pinus halepensis Mill. and Pinus pinea L Plant Ecology 171, 139151.

Russell-Smith, J., Yates, C.P., Brock, C., Westcott, V.C., 2010 Fire regimes and interval-sensitive vegetation in semiarid Gregory National Park, northern Australia Australian Journal of Botany 58, 300-317.

Sande Silva, J., Rego, F., Fernandes, P., Rigolot, E., (Eds.), 2010 Towards Integrated Fire Management - Outcomes of the European Project Fire Paradox European Forest Institute Research Report 23 (European Forest Institute) $228 \mathrm{pp}$.

Saura-Mas, S., Paula, S., Pausas, J.G., Lloret, F., 2010 Fuel loading and flammability in the Mediterranean Basin woody species with different post-fire regenerative strategies International Journal of Wildland Fire 19, 783-794.

Schaffhauser, A., Curt, T., Tatoni, T., 2011 Fire-vegetation interplay in a mosaic structure of Quercus suber woodlands and Mediterranean maquis under recurrent fires Forest Ecology and Management 262, 730738.

Smith, P., 2002 Analysis of failure and survival data Chapman \& Hall / CRC Press, Boca Raton

Syphard, A.D., Radeloff, V.C., Keeley, J.E., Hawbaker, T.J., Clayton, M.K., Stewart, S.I., Hammer, R.B., 2007 Human influence on California fire regimes Ecological Applications 17, 1388-1402.

Trabaud, L., 1998 Are wildland fires threatening the Mediterranean flora and vegetation? Advances in ecological sciences. Volume 1: Ecosystems and sustainable development. 137-146.

Turner, M.G., 1989 Landscape ecology - The effect of pattern on process Annu. Rev. Ecol. Syst. 20, 171-197.

van Wilgen, B.W., Forsyth, G.G., de Klerk, H., Das, S., Khuluse, S., Schmitz, P., 2010 Fire management in Mediterranean-climate shrublands: a case study from the Cape fynbos, South Africa Journal of Applied Ecology 47, 631-638.

Vazquez, A., Moreno, J.M., 2001 Spatial distribution of forest fires in Sierra de Gredos (Central Spain) Forest Ecology and Management 147, 55-65. 